ks. Lech Król ${ }^{1}$

Uniwersytet Mikołaja Kopernika

\title{
Misja profetyczna św. Faustyny Kowalskiej i jej znaczenie dla Kościoła we współczesnym świecie
}

Misję profetyczną św. Faustyny Kowalskiej określił i ogłosił Chrystus słowami jej posłania: „W Starym Testamencie wysyłałem proroków do ludu swego [...]. Dziś wysyłam ciebie do całej ludzkości z moim miłosierdziem" ${ }^{2}$. Wcześniej przygotowywał ją do tego zadania, które poznała, zaakceptowała i wiernie realizowała.

80. rocznica jej śmierci, przypadająca w tym roku, uświadamia, iż na tej drodze osiągnęła świętość życia. Tak ocenił ją Kościół, któremu służyła gorliwie i z oddaniem. Jan Paweł II, kanonizując Faustynę (2003) jako pierwszą świętą III tysiąclecia chrześcijaństwa, potwierdził, że jest wzorem życia chrześcijańskiego. Z pewnością jej misji nie da się zredukować

1 Ks. Lech Król - dr hab. teologii duchowości chrześcijańskiej, pracuje na WT UMK i w Studium Teologii we Włocławku przy Papieskiej Akademii Teologii Sekcja św. Jana Chrzciciela w Warszawie. Autor kilkudziesięciu artykułów naukowych i książki Charyzmat Zgromadzenia Służebnic Najświętszego Serca Jezusowego, Włocławek 2012. Członek zwyczajny Polskiego Stowarzyszenia Teologów Duchowości, prezes Teologicznego Towarzystwa Naukowego Wyższego Seminarium Duchownego we Włocławku i redaktor „Studiów Włocławskich". E-mail: x.lechkrol@wp.pl.

2 Św. M. F. Kowalska, Dzienniczek. Miłosierdzie Boże w duszy mojej, Warszawa 2001, nr 1588 [dalej: Dz.]. 
do przekazania tylko samych form kultu miłosierdzia Bożego, który polega na uwielbianiu go i wypraszaniu dla Kościoła i dla świata. Chrystus bowiem wskazał s. Faustynie na elementy treściowe tej misji: „Podaję ci trzy sposoby czynienia miłosierdzia [...]: pierwszy - czyn, drugi - słowo, trzeci - modlitwa; w tych trzech stopniach zawiera się pełnia miłosierdzia [...]"3. Wpierw odsłonił jej, że żąda od ludzi czci dla miłosierdzia Bożego, a ona pierwsza winna ją podejmować i odznaczać się bezwarunkową ufnością ${ }^{4}$.

Ponieważ Chrystus powierzył to zadanie prostej, ale świętej zakonnicy, dlatego wydawać by się mogło, że jest ono jej osobistą misją. W rzeczywistości ma charakter eklezjalny, i to z wielu względów. Szczególnie zaś z tytułu sakramentów inicjacji chrześcijańskiej: chrztu świętego i bierzmowania. Zatem wpisane jest w misję Kościoła, którą winien podejmować w duchu treści przekazanych s. Faustynie. Mają one szczególne znaczenie dla jego misji, których jest własnością. Chrystus żąda w nich „od ludzi czci dla [swojego] miłosierdzia”, a doznaje jej, gdy zanurza się w nim grzeszników całego świata ${ }^{6}$.

W misji profetycznej św. Faustyny jest obecny także aspekt eschatologiczny: ma przygotować ludzkość na powtórne przyjście Chrystusa.

Misję tę realizowała według Jego wskazań: w modlitwie, w słowach i w dziełach. Ponieważ jest ona wpisana w naturę Kościoła, dlatego jej gorliwa realizacja jest dla niego wzorem zaangażowania w jej kontynuację. Kościół bowiem, jednając i jednocząc ludzi z Bogiem i ze sobą, ma być w świecie wiarygodnym znakiem miłosierdzia Bożego ${ }^{7}$. Sakramentalne zaś obdarowanie daje w Kościele możliwość bycia miłosiernym jak Ojciec: przez modlitwę, słowa i uczynki. Powyższa triada, jak powiedział Chrystus, zawiera w sobie pełnię „miłosierdzia i jest niezbitym dowodem

3 Dz. 742; por. A. Witko, Święta Faustyna i Miłosierdzie Boże, Kraków 2007, s. 93-94.

4 Por. Dz. 742; L. Grygiel, Miłosierdzie Boże dla całego świata. Błogosławiona Siostra Faustyna, Kraków 1993, s. 37-41.

5 Por. Dz. 742.

6 Por. Dz. 206.

7 Sobór Watykański II, konst. Lumen gentium [dalej: KK], 1. 
miłości ku Mnie. W ten sposób dusza wysławia i oddaje cześć miłosierdziu mojemu"s.

Tak więc logika powyższych elementów treściowych wyznacza strukturę niniejszego artykułu.

\section{Modlitwa}

Wezwanie do modlitwy o dar miłosierdzia Bożego dla świata jest istotnym elementem treściowym orędzia św. Faustyny. Struktura treściowa Dzienniczka, w którym zostało ono utrwalone, wskazuje na jego głębokie osadzenie w rzeczywistości modlitwy. Ono w niej się zawiera i z niej wyrasta. Zawiera jednocześnie wiele form modlitwy i zajmuje się modlitwą jako taką. W takiej konstelacji nasuwa się pytanie o relacje istniejące między misją profetyczną św. Faustyny a modlitwą. Odpowiedź znajdujemy w słowach Jezusa skierowanych do niej: ,Jeżeli [ludzie] nie uwielbią miłosierdzia mojego, zginą na wieki"'. Ponieważ miłosierdzie Boże ma charakter uniwersalny, wszyscy są wezwani do modlitwy. Chrystus, przypominając o tym Kościołowi, wskazał na kilka form modlitwy, w których winno być czczone ${ }^{10}$.

W cytowanych powyżej słowach Jezusa współbrzmią ze sobą dwa istotne elementy treściowe: uwielbienie, czyli modlitwa, i Jego miłosierdzie. Zatem nasuwa się pytanie: czym powinno być nabożeństwo do miłosierdzia Bożego, samo w sobie, w praktyce? Z pewnością w duchu słów Jezusa winno mieć charakter modlitwy. W niej zaś akcentuje szczególną rolę uwielbiania, czci i chwały wobec miłosierdzia Bożego, będącego owocem miłości Boga Trójjedynego. Zatem ma wymiar kultu chrześcijańskiego, który jako taki ma naturę modlitwy Kościoła adresowanej do Boga Ojca przez Chrystusa w Duchu Świętym. W strukturę tegoż kultu wpisane są wszelkie akty czci oddawanej miłosierdziu Bożemu, to znaczy: adoracja, ufność oraz pozostałe formy i rodzaje modlitwy. Przynależy do nich

\footnotetext{
Dz. 743.

Dz. 965; por. L. Grygiel, Miłosierdzie Boże dla całego świata..., dz. cyt., s. 46-47.

Por. W. Seremak, Miłosierdzie Boże a nowa ewangelizacja. Znaki czasu, Lublin 2001, s. 105.
} 
także pięć form nabożeństwa, które Chrystus przekazał przez s. Faustynę Kościołowi i światu ${ }^{11}$. Winni je praktykować wszyscy, ponieważ są adresatami tego orędzia. Szczególnie akcentuje On wartość modlitwy - koronki do miłosierdzia Bożego, ponieważ uśmierza gniew Boży i przybliża do Boga ${ }^{12}$. W kult ten wpisane jest także przepowiadanie mające charakter głoszenia chwały Boga, którego miłosierdzie jest niezgłębione ${ }^{13}$, nieskończone ${ }^{14}$, niepojęte ${ }^{15}$, niezbadane ${ }^{16}$, niewypowiedziane ${ }^{17}$, niewyczerpane $^{18}$ i niezmierzone ${ }^{19}$.

W takim duchu powinna być kierowana, według Dzienniczka, każda modlitwa chrześcijańska. Treścią każdej z nich jest nie tylko miłosierdzie Boga w Trójcy Świętej, ale także miłosierdzie Boga Ojca i bosko-ludzkie miłosierdzie Serca Jezusa. Głównym jej adresatem, według wybitnego teologa ks. Ignacego Różyckiego, jest Jezus, ponieważ celem wszystkich form modlitw, także do miłosierdzia Bożego, jest Jego Osoba. Jest nawet tak, gdy są kierowane do innej Osoby Boskiej. Chrystus bowiem, jako jedyny Pośrednik, jest dawcą wszystkich łask, także tych udzielanych w omawianym kulcie. Jednak według św. Jana Pawła II czcimy w tym nabożeństwie miłosierdzie Boga Trójjedynego ${ }^{20}$. Zatem nie może się ono sprowadzać tylko do kultu miłosierdzia Bożego ucieleśnionego w Osobie Jezusa Chrystusa.

Chrześcijanin zaś, jak pisze św. Faustyna, winien modlić się w każdym stanie swojego wnętrza i życia, ponieważ wszelka łaska, a więc także

11 Por. A. Witko, Święta Faustyna i Miłosierdzie Boże, dz. cyt., s. 101-273; J. K. Miczyński, Fundament duchowości i charyzmat Zgromadzenia Sióstr Matki Bożej Miłosierdzia, Lublin 2016, s. 106-107; M. Chmielewski, Duchowość Miłosierdzia. Mały katechizm, Lublin 2017, s. 122-125.

12 Por. Dz. 476.

13 Por. Dz. 570, 810-811, 848, 1059, 1142, 1146, 1190, 1521.

14 Por. Dz. 378-379, 687-689.

15 Por. Dz. 177, 699, 1182.

16 Por. Dz. 1146.

17 Por. Dz. 359.

18 Por. Dz. 47-50, 1273.

19 Por. Dz. 1273.

20 Por. Jan Paweł II, enc. Dives in Misericordia. Tekst i komentarz [dalej: DiM], 1-5; A. Witko, Święta Faustyna i Miłosierdzie Boże, dz. cyt., s. 87-92; J. Misiurek, Źródło życia i świętości. Polska Teologia kultu Najświętszego Serca Jezusa, Lublin 2014, s. 87-97; J. Misiurek, Wielkie mistyczki Kościoła, Lublin 1999, s. 195-204. 
dar miłosierdzia, spływa przede wszystkim w modlitwie ${ }^{21}$. Ono staje się dostępne w zasięgu ufnej i wytrwałej modlitwy przenikniętej pragnieniem otrzymania darów miłosierdzia Bożego. Należy więc jasno stwierdzić, że odwieczny plan zbawienia, owoc tegoż miłosierdzia, rozwija się i dopełnia nie inaczej, jak w modlitwie. Bóg pragnie obdarowywać nim z najpełniejszą hojnością, ale uzależnia je od modlitwy, będącej kluczem do Jego miłosierdzia. Chrystus powiedział s. Faustynie, że dusze ludzkie zdobywa modlitwą złączoną z ofiarą ${ }^{22}$.

Modlitwa prośby, a taką jest modlitwa do miłosierdzia Bożego, winna być ufna. Jedynie człowiek ufający bezgranicznie Bogu pośredniczy między Nim a ludźmi. Tylko tak wyprasza się Jego miłosierdzie dla wszystkich: dla Kościoła, dla świata i dla poszczególnych ludzi. Taka modlitwa wyprasza, ,aby raz jeszcze na tym etapie dziejów objawiła się owa Miłość, która jest w Ojcu, aby za sprawą Syna i Ducha Świętego okazała się obecną w naszym współczesnym świecie i potężniejszą niż zło, potężniejszą niż grzech i śmierć"

Siostra Faustyna pisze w Dzienniczku, że Jezus polecał jej modlitwie nie tylko pojedynczych ludzi, ale także mieszkańców jednego z miast polskich ${ }^{24}$. Prosił o gorącą modlitwę za grzeszników, za konających, za mieszkańców całego świata, za nieprzyjaciół, za prezbiterów i za wychowanki zakładu prowadzonego przez jej zgromadzenie. Mówił, że „miłość ich jest słaba, dlatego oddaję ci je pod szczególną opiekę; módl się za nie" ${ }^{25}$. W procesie zaś rozeznawania powołania życiowego brata poznała i zrozumiała, ,że w tej sprawie pożyteczniejsza jest modlitwa aniżeli rada..." ${ }^{26}$.

Należy więc zauważyć, że s. Faustyna misję prorocką wypełniała najpierw w modlitwach polecanych przez Jezusa. Realizowała w nich

21 Por. Dz. 146; L. Grygiel, Miłosierdzie Boże dla całego świata..., dz. cyt., s. 50-52.

22 Por. M. Sopoćko, Miłosierdzie Boga w dziełach Jego, t. 3: Duch Święty, Kościół, łaska, cnota, dary Ducha Świętego, modlitwa, ufność, sakramenty święte, wyd. 3, Białystok 2017, s. 147-149.

${ }_{23}$ DiM, 15; por. B. Rychłowski, Jestem miłością i samym miłosierdziem. Orędzie Pana do błogosławionej siostry Faustyny, Warszawa 1994, s. 101-106.

24 Por. Dz. 39.

25 Dz 288; por. 247, 435, 1160, 1320, 1541, 1628, 1777.

26 Dz. 1290. 
Jego zbawczą wolę, aby miłosierdzie Boże miało możliwość dotarcia i działania w sercu wszystkich ludzi ${ }^{27}$. Podejmowała ją gorliwie i z oddaniem. Wstawiała się, z bezgraniczną ufnością, w sprawach polecanych osób, Kościoła, Polski, a także poszczególnych narodów świata. W jednej z modlitw Chrystus prosił ją: „Odpraw nowennę za Ojczyznę. Nowenna ta będzie się składać $z$ litanii do Wszystkich Świętych" ${ }^{28}$. W jej realizacji otrzymała łaskę widzenia mistycznego, w którym Bóg Ojciec patrzył przez krzyż Jezusa i Jego rany na ziemię. Wizja była obrazową koncepcją miłosierdzia Boga wypraszanego wytrwałą modlitwą. Ona była codzienną praktyką jej życia duchowego. Rozmawiała w niej z Bogiem, przed którym otwierała się na ludzi, wypraszając im łaskę Jego miłosierdzia ${ }^{29}$.

Chrystus na drodze modlitwy przygotował s. Faustynę na szczególne obdarowanie nadprzyrodzone, w którym otrzymała dar proroctwa, poznawania serc innych ludzi, odległych rzeczy i faktów. Wśród nich także dar ekstaz i szczególnych wizji mistycznych ${ }^{30}$. W takim wyposażeniu była w stanie realizować otrzymaną misję. Tak stała się darem Boga dla Kościoła i dla świata. Była świadoma swojego posłannictwa w Kościele i w świecie. Na nie wskazał Jezus, kiedy ją prosił: „daj mi dusze; wiedz, że zadaniem twoim jest zdobywać mi dusze modlitwą i ofiarą" ${ }^{31}$. Wielokrotnie też przekonywał ją, że „modlitwą i cierpieniem więcej zbawisz dusz, aniżeli misjonarz przez same tylko nauki i kazania"32. Dlatego nie dziwi, że czuła się powołana do wypraszania miłosierdzia Bożego w codziennej modlitwie. Już od wczesnych lat życia charakteryzowała się duchem rozmodlenia i skupienia wewnętrznego. Podejmowała ją gorliwie i z wdzięcznością, ponieważ traktowała jako formę współpracy z Bogiem miłosiernym.

27 Por. Dz. 245; L. Grygiel, Miłosierdzie Boże dla całego świata..., dz. cyt., s. 47-50.

28 Dz. 59.

29 Por. Dz. 59.

30 Por. S. Urbański, Mistyczny świat ducha, Warszawa 2000, s. 151-169.

31 Dz. 1690; por. Dz. 481-482; M. Chmielewski, Duchowość Miłosierdzia..., dz. cyt., s. $186-192$.

32 Dz. 1767. 
Duch zaś rozwijającej się modlitwy owocował w życiu duchowym św. Faustyny realizacją woli Bożej ${ }^{33}$, a także postawą odpowiedzialności za Kościół, ojczyznę i świat. Odznaczała się jasnością widzenia uniwersalnego wymiaru otrzymanego posłannictwa. To odczucie wyraziła słowami Dzienniczka: „zdaje mi się, że świat cały ode mnie zależy”34. Była przekonana, że jest powołana do ratowania całej rodziny ludzkiej, do której Bóg posyła ją z orędziem miłosierdzia. W tym więc duchu przebiegała drogą modlitwy poszczególne części świata i docierała aż do najdalszych zakątków. Do niej też zachęcała wszystkich członków Mistycznego Ciała Chrystusa. Charakteryzowała się pewnością przekonania, że jej podstawowym zadaniem jest ratowanie tą drogą każdego człowieka. W niej wyraża się, jak napisała, „[...] miłość do Kościoła. [Dlatego] Jak dobre dziecko [...], każda dusza chrześcijańska powinna się modlić za Kościół, który jest dla niej Matką" ${ }^{35}$. W niej urzeczywistnia się miłość do całego świata, w intencjach którego Kościół składa Bogu wraz z modlitwą ofiary błagalne. Taka realizacja powołania chrześcijańskiego „przyniesie radość Kościołowi" ${ }^{36}$.

Klimatem niezbędnym do modlitwy do miłosierdzia Bożego, jak uczy św. Faustyna, jest postawa zaufania wobec Boga i dyspozycyjność do obdarowywania nim każdego człowieka. Te elementy streszczają się w słowach krótkiej modlitwy, której nauczył ją Chrystus: „Jezu, ufam Tobie”37. Pragnął, aby niosła w niej dar miłosierdzia Bożego całemu światu. W tym celu przekazał ją Kościołowi, któremu służyła ofiarnie w realizacji jego misji ${ }^{38}$. Wydaje się, że treść tej krótkiej modlitwy koresponduje ze słowami Jezusa: „To Ja jestem, nie bójcie się!” (J 6, 20). Czyż nie jest ona przyodziana Jego autorytetem? Dlatego rodzi pewność, że oczekuje w niej postawy ufności w ciemno względem swojego miłosierdzia. Potwierdza to, gdy mówi, że: „Najmilsza jest mi ta dusza, która wierzy

33 Por. J. K. Miczyński, Fundament duchowości i charyzmat Zgromadzenia Sióstr Matki Bożej Miłosierdzia..., dz. cyt., s. 257-263.
4 Dz. 870.
5 Dz. 551.
36 Dz. 551; por. L. Grygiel, Miłosierdzie Boże dla całego świata..., dz. cyt., s. 52-58.
37 Dz. 47; por. Dz. 300, 742, 1578.
38 Dz. 641. 
mocno w dobroć Moją i zaufała Mi zupełnie [...] i daję jej wszystko, o co prosi" ${ }^{39}$. Zapewne te słowa należy interpretować w kategoriach wezwania do bezgranicznej ufności Jego miłosierdziu w najbardziej trudnych doświadczeniach życia. Chodzi tu o postawę ufności bezwarunkowej wobec Osoby Boga, który w miłosierdziu swoim nie pozostawia nigdy człowieka w życiowych uwikłaniach. Dla Niego bowiem nie ma nic niemożliwego (por. Łk 1,37).

Zatem ta krótka, ale bogata w treść modlitwa stawia w centrum każdej modlitwy postawę zaufania Panu Bogu. Wtedy jest ona jakby klamrą spinającą całokształt spraw życia ludzkiego przedstawianych Jego miłosierdziu. Dlatego s. Faustyna powtórzyła za o. Andraszem, że byłoby dobrze, aby w Kościele powstały grupy ludzi stale wypraszających miłosierdzie Boże, którego światu bardzo potrzeba ${ }^{40}$.

Niezbędnym więc warunkiem urzeczywistniania się obietnic, związanych z tym orędziem, jest ufność miłosierdziu Bożemu i gotowość do obdarowywania nim ludzi, tak w słowach, jak i w pełnionych czynach.

\section{Słowa}

Kolejnym elementem treściowym misji, jaką otrzymała św. Faustyna, jest przepowiadanie prawdy o miłosierdziu Bożym. Bóg nie tylko przypomniał o nim światu, ale ukazał drogi prowadzące do poznania jego istoty, czym ono jest w swej treści. Ta misja wynika z mandatu Jezusa: „Wysyłam ciebie do całej ludzkości z Moim Miłosierdziem"41. Niejako przynaglał ją: „Powiedz zbolałej ludzkości, niech się przytuli do miłosiernego Serca Mojego, a Ja ich napełnię pokojem"42. Obie powyższe frazy stanowią niejako syntezę jej misji, którą można sformułować następująco: przepowiadaj wszystkim ludziom prawdę o miłosierdziu Bożym. Tak też czyniła, ponieważ zawiera w sobie miłość miłosierną Boga troszcząca się o zba-

\footnotetext{
39 Dz. 453; A. Witko, Święta Faustyna i Miłosierdzie Boże, dz. cyt., s. 92-93.

40 Por. Dz. 623; Katechizm Kościoła Katolickiego, Poznań 1994 [dalej: KKK], 1477.

$41 \quad$ Dz. 1588.

42 Dz. 1074.
} 
wienie ludzi. Ponieważ przed ludzkością piętrzą się różnorakie zagrożenia, Chrystus ukazuje w miłosierdziu Bożym źródło ocalenia, ratunku i wyzwolenia ${ }^{43}$. Wzywa Kościół i świat do takiego poznania miłosierdzia Bożego, aby zaowocowało zaufaniem względem niego i należną czcią. Wówczas zrodzi się imperatyw przynaglający do głoszenia tej prawdy i do świadczenia o niej w konkretnych dziełach miłosierdzia. W procesie jego poznawania modlitwa o miłosierdzie będzie logiczną potrzebą ser$\mathrm{Ca}^{44}$. Dlatego nie dziwi, że Chrystus wielokrotnie przynaglał s. Faustynę, aby pisała i mówiła o nim jako o największym przymiocie Boga. Mówił wprost: „Powiedz duszom, aby nie stawiały tamy mojemu miłosierdziu we własnym sercu, które tak bardzo pragnie w nich działać" 45 .

Misja św. Faustyny ma więc konkretny, jasno określony cel - szerzenie czci miłosierdzia Bożego i dzieł miłosierdzia Bożego. W tym aspekcie jest ona nową misją, a jego treścią jest miłość Boża wytryskująca z głębi wewnętrznego życia Trójcy Świętej, a objawiająca się najpełniej na krzyżu Zbawiciela ${ }^{46}$. Jego męka i śmierć były dla s. Faustyny dowodem miłości Boga i Jego miłosierdzia, których owoce dostępne są w sakramentach świętych. Tajemnica jej powołania była ukierunkowana od samego początku na funkcję przepowiadania prorockiego, które w jej misji ma istotne miejsce. Myśl tę dobitnie oddają słowa, jakie zapisała w Dzienniczku: „Pragnę mówić [...] o Twojej dobroci i zachęcać do ufności w miłosierdzie Twoje to jest misja moja,którąśmi przeznaczył,Panie, w tymi przyszłym życiu" ${ }^{47}$.

W jej strukturę wprowadzał ją sukcesywnie, o czym świadczą objawienia, jakich udzielał ${ }^{48}$. W tajemnicy szczególnego powołania ustanowił ją dosłownie sekretarką Bożego miłosierdzia „w tym i przyszłym życiu" ${ }^{49}$. Przygotował ją do tej funkcji drogą udzielanych objawień i ob-

43 Por. DiM 11.

44 Por. W. Seremak, Miłosierdzie Boże a Nowa Ewangelizacja..., dz. cyt., s. 95-108.

45 Dz. 1577.

46 Por. Dz. 949; 1190; DiM 7-8; M. Dłutowski, Przygotujesz świat na ostateczne przyjście moje. Profetyczna misja św. Faustyny Kowalskiej na podstawie Dzienniczka, Ząbki 2016, s. 71.

47 Dz. 1325.

48 Por. Dz. 1588; por. M. Dłutowski, Przygotujesz świat na ostateczne przyjście moje..., dz. cyt., s. 67.

49 Dz. 1605; por. M. Chmielewski, Duchowość Miłosierdzia. Mały katechizm, Lublin 2017, s. 185-189; L. Balter, Kult Miłosierdzia Bożego w świetle „Dzienniczka” św. Faustyny, „Ateneum 
darowując darami duchowymi. One służyły poznawaniu orędzia i pomagały w przekazywaniu jego elementów treściowych. Nie mogło być inaczej, skoro zadaniem s. Faustyny było przekazywanie ludziom prawdy o Bożym miłosierdziu i troska, aby nie stawiano przed nim żadnej tamy $^{50}$. Ukazywała je jako obecność Boga, miłującą i towarzyszącą ludziom w każdym momencie życia.

Szczególnymi adresatami tego orędzia byli prezbiterzy. Chrystus oczekuje od nich włączenia się w misję głoszenia miłosierdzia Bożego. Chodziło Mu zwłaszcza o kazania głoszone w święto ku czci Jego miłosierdzia ${ }^{51}$. Nadto wskazał s. Faustynie jeszcze innych adresatów, jak ks. Michała Sopoćkę - jej kierownika duchowego czy przełożoną domu. Zarysował też potrzebę powołania do istnienia nowego zgromadzenia zakonnego dla głoszenia tegoż orędzia. Tak więc św. Faustyna poznawała odwieczny zamysł Boga pragnącego obdarowywać ludzi swoim miłosierdziem. Doświadczając tej tajemnicy, współczuła Mu, gdy mówił: „Palą Mnie płomienie miłosierdzia, chcę je wylewać na dusze” ${ }^{52}$. Dlatego duchowe jej obdarowanie było podporządkowane całkowicie nauczaniu prorockiemu.

Zatem posłannictwo s. Faustyny jest wolą Chrystusa, objawiającego cel tego wybrania - upowszechniać treść powierzonej misji. Powiedział: „Ile razy chcesz Mi sprawić radość - to mów światu o Moim wielkim i niezgłębionym miłosierdziu" ${ }^{53}$. Miała ją urzeczywistniać w słowie przepowiadanym i pisanym. W tym więc celu polecił, aby spisywała otrzymane orędzie, w które wprowadzał w udzielanych objawieniach. Nawet nakazał jej: „[...] żądam, abyś wszystkie wolne chwile poświęciła na pisanie o mojej dobroci i miłosierdziu; jest to twój urząd i twoje zadanie w całym twym życiu, abyś dawała duszom poznać moje wielkie miłosierdzie [...]"54. To, co poznała w sposób nadprzyrodzony i co usłyszała,

Kapłańskie" 85 (1993), s. 495-499.

50 Por. Dz. 177, 301, 1577; A. Witko, Święta Faustyna i Miłosierdzie Boże, dz. cyt., s. 234-235;

L. Grygiel, Miłosierdzie Boże dla całego świata..., dz. cyt., s. 40.

51 Por. Dz. 50, 300, 302, 949, 1072, 1521.

52 Dz. 177.

53 Dz. 164.

54 Dz. 1567; por. Dz. 180. 
było treścią przekazywanej misji. Chrystus pragnął, aby tą drogą dotarła do jak najszerszej populacji ludzi, aby otrzymali możliwość poznawania treści tego orędzia. Realizacja tej misji służy ostatecznie przygotowaniu świata na Jego ostateczne przyjście, zatem ma znamiona eschatologiczne. Zapewne w tym celu otrzymała wizję nieba, czyśćca i piekła ${ }^{55}$.

$\mathrm{W}$ tajemnicę powołania s. Faustyny jest też wpisany dar przewidywania przyszłości. Dlatego poznawała przyszłe wydarzenia, odnoszące się także do Polski. Wydaje się, że ów dar inspirował ją do gorliwej realizacji otrzymanej misji. Fakt powtórnego przyjścia Zbawiciela, który będzie ostatecznym spotkaniem człowieka z Bogiem, przynaglał ją do mówienia i pisania o Jego miłosierdziu. Pisze, że obecny czas jest czasem miłosierdzia, a paruzja będzie już czasem sprawiedliwości, która nadejdzie. Tak więc jest on dla Kościoła, w perspektywie misji profetycznej s. Faustyny, czasem wytężonej pracy, ratowania dusz i zanurzania ich w nieskończonym miłosierdziu Boga, czyli czasem intensywnego poświęcania się sprawie zbawienia całego świata ${ }^{56}$.

Tak więc Chrystus ustanowił s. Faustynę promotorką tegoż orędzia, która zabiegała o jego promulgację i o formację postawy zaufania miłosierdziu Bożemu. Zaufanie jest jednym z najważniejszych elementów jego czci, ponieważ w tej perspektywie urzeczywistnia się jego uwielbienie, dające nieograniczone możliwości czerpania bogactwa łask. W tej konwencji niektórzy teologowie uważają św. Faustynę za proroka ufności miłosierdziu Bożemu, która jest ukierunkowana na zbawcze dzieło Chrystusa.

Taki jest cel kultu miłosierdzia Bożego, jaki Chrystus przypomniał, w misji profetycznej św. Faustyny, Kościołowi i światu. ${ }^{57}$ Zatem Kościół jest wezwany do kontynuacji tej misji na wielorakich odcinkach pracy ewangelizacyjnej i duszpasterskiej, w które wpisana jest także bogata różnorodność dzieł miłosierdzia.

55 Por. Dz. 20, 741, 777; M. Dłutowski, Przygotujesz świat na ostateczne przyjście moje..., dz. cyt., s. 76-77; J. K. Miczyński, Fundament duchowości i charyzmat Zgromadzenia Sióstr Matki Bożej Miłosierdzia..., dz. cyt., s. 271-281.

56 Por. L. Grygiel, Miłosierdzie Boże dla całego świata..., dz. cyt., s. 48; DiM 13.

57 Por. M. Dłutowski, Przygotujesz świat na ostateczne przyjście moje..., dz. cyt., s. 70, 78-85. 


\section{Dzieła miłosierdzia}

Święta Faustyna, doświadczając największych przymiotów Boga: miłości i miłosierdzia, zrozumiała, że „miłosierdzie jest kwiatem miłości, Bóg jest miłością, a miłosierdzie jest Jego czynem, w miłości się poczyna, w miłosierdziu się przejawia" ${ }^{8}$. W duchu tych słów Bóg jawi się jako Bóg czynu, co objawia w tajemnicy stworzenia świata i jego odkupienia ${ }^{59}$.

Owocem poznawanego i doświadczanego miłosierdzia Bożego jest miłosierdzie umiejscawiające się w sercu człowieka, który wtedy obdarowuje nim spotykanych ludzi. Według papieża Franciszka „Miłosierdzie jest podstawowym prawem, które mieszka w sercu każdego człowieka, gdy patrzy on szczerymi oczami na swojego brata, którego spotyka na drodze życia" ${ }^{0}$. Tak odzwierciedla w sobie miłosierdzie Boże, z którym wychodzi naprzeciw spotykanym ludziom. Zadomowiło się ono głęboko w sercu św. Faustyny, dlatego Chrystus przynaglał ją, aby dzieliła się nim z całym światem. On bowiem pragnął przez jej posługę „dotknąć [nim] serce i umysł każdego człowieka"61. W Dzienniczku widoczne jest jej ofiarne i pełne oddania, zaangażowanie na rzecz dawania tegoż miłosierdzia.

Dlatego nie dziwi, że tyle miejsca poświęciła w nim realizacji miłosierdzia czynnego w różnych dziełach miłości. One przecież, zgodnie z nauczaniem II Soboru Watykańskiego, należą do pierwszych zadań Kościoła $^{62}$. Wraz z misją przepowiadania orędzia miłosierdzia Bożego ma podejmować wynikające zeń dobroczynne dzieła ${ }^{63}$. Ponieważ Chrystus jest uosobieniem Kościoła, dlatego jako Mistyczne Ciało Zbawiciela Kościół ma ją urzeczywistniać w różnorodnych dziełach dobroczynnych. W nim bowiem bije źródło miłosierdzia, które chce przybierać kształt konkretnych dzieł. Dlatego kontemplując tajemnicę powołania s. Faustyny, winien jak ona angażować się w dzieło obdarowywania nimi ludzi obecnego czasu. Takie jest zadanie Kościoła, a więc jego hierarchii,

Dz. 651; por. L. Grygiel, Miłosierdzie Boże dla całego świata..., dz. cyt., s. 39-40.

Por. DiM 4, 7; KKK 295.

MV 2; por. S. Urbański, Mistyczny świat ducha, dz. cyt., s. 103-121.

MV 12; por. A. Witko, Święta Faustyna i Miłosierdzie Boże, dz. cyt., s. 93-95.

Por. KK 88; Sobór Watykański II, konst. Gaudium et spes, 42.

Por. DiM 14; Sobór Watykański II, Dekret o apostolstwie świeckich, 8. 
osób życia konsekrowanego i wiernych świeckich chrześcijan. Od ich realizacji, jak pisze w Dzienniczku, „[...] zależy chwała Kościoła i postęp niejednej duszy [...]"64.

Obowiązek czynnego miłosierdzia jest logicznym następstwem odkrywanego i doświadczanego miłosierdzia Bożego. Tylko wtedy można być „miłosiernym jak Ojciec” ${ }^{\prime 6}$. Ta zaś postawa realizuje się w uczynkach miłosierdzia tak wobec duszy, jak i ciała. Pragnie ono bowiem obejmować zbawczym dynamizmem całego człowieka, a więc wszystkie jego władze. Jego zaś imperatywem jest miłość bliźniego, którą Chrystus stawia obok miłości Boga. Ponieważ integralnie stanowią najważniejsze przykazanie, dlatego bez miłości Boga realizacja miłosierdzia Bożego jest niemożliwa ${ }^{66}$. Jednak w dzieła dobroczynne względem duszy człowieka, wpisuje się najpierw modlitwa o miłosierdzie Boże. Winna być prośbą wołającą o przebaczenie grzechów i towarzyszącą ludziom konającym. Tak ją rozumie św. Jan Paweł II, dla którego jest ona wołaniem o miłosierdzie Boga wobec zła ciążącego nad światem i zagrażającego współczesnej ludzkości $^{67}$. W swej istocie winna odwoływać się do miłości Boga, gotowego przebaczać najcięższe grzechy. W tym kontekście bardziej rozumiemy, dlaczego Chrystus przekazał s. Faustynie różne formy modlitw do miłosierdzia Bożego.

Poza tym św. Faustyna głosiła je i realizowała w wielorakich czynach wpisujących się w apostolstwo życia chrześcijańskiego. Ludzkość potrzebuje rzeczywiście takich jak ona nauczycieli miłosierdzia, którzy są jednocześnie jego świadkami. Dzieła miłosierdzia z natury swojej mają charakter apostolskiego świadczenia o miłosierdziu Bożym, ponieważ wyrastają i muszą wyrastać z niego jak ze źródła. Do ich realizacji Chrystus

64 Dz. 508, 551; por. DiM 13.

65 MV 13.

66 Por. Dz. 664; MV 15; KKK 1829, 2300, 2447; M. Sopoćko, Miłosierdzie Boga w dziełach Jego, t. 1: Wcielenie - życie, nauczanie i czyny Jezusa Chrystusa, wyd. 3, Białystok 2017, s. 188-208; M. Sopoćko, Miłosierdzie Boga w dziełach Jego, t. 3: Duch Święty, Kościót, łaska, cnota, dary Ducha Świętego, modlitwa, ufność, sakramenty święte, wyd. 3, Białystok 2017, s. 215-219; J. Misiurek, Źródło życia i świętości. Polska Teologia kultu Najświętszego Serca Jezusa, Lublin 2014, s. 145-149; M. Chmielewski, Duchowość Miłosierdzia..., dz. cyt., s. 149-179.

${ }_{67}$ Por. DiM 15; KKK 1606-1609; M. Chmielewski, Duchowość Miłosierdzia..., dz. cyt., s. $215-216$. 
wzywał ją wielokrotnie, a nawet przynaglał, o czym pisze w Dzienniczku: „Żądam od ciebie uczynków miłosierdzia, które mają wypływać z miłości ku Mnie" ${ }^{68}$. Przynaglał ją do naśladowania Jego miłości i Jego miłosierdzia do wszystkich ludzi bez wyjątku. Motywacją zaś takiej postawy musi być miłość do Boga. Wszystkie więc dobroczynne dzieła Kościoła winny wyrastać z miłości do Niego, ponieważ On jest miłością i tak świat umiłował, że dał mu swojego Jednorodzonego Syna (por. J. 3, 16-17). Zatem idąc po myśli objawień udzielonych s. Faustynie, podejmowane dzieła winny być owocem doświadczanego miłosierdzia Bożego. Tylko wtedy będzie ono realizowane na co dzień. Siostra Faustyna pisze, że Chrystus powyższe żądania adresuje zarówno do niej, jak i do całego Kościoła, szczególnie zaś do osób zakonnych. Ponieważ w spełnianych dziełach odzwierciedla się Jego miłosierdzie, ludzkość może je w nich zobaczyć, oglądać, a więc doświadczać. W taki sposób Kościół wraz ze swoją misją staje się wiarygodny, a tym samym przekonujący wobec swoich adresatów.

Według papieża Franciszka „wiarygodność Kościoła weryfikuje się na drodze miłości miłosiernej i współczującej”69. Świadectwo czynów miłosiernych ma bowiem charakter ewangelizacyjny, ponieważ potwierdzają wiarygodność nauczania Kościoła. Dotyczy także miłosierdzia Bożego przypominającego objawioną już w tajemnicy odkupienia prawdę o przebaczeniu wymazującym grzechy świata. Ponieważ Bóg rozlał w nim swoje miłosierdzie na całe stworzenie, mimo kumulującego się arsenału zła nie niszczy go ani nie karze. Jako Odkupiciel jedynie czeka na jego przyjęcie i na rezonans duchowy w życiu ludzi dobrej woli ${ }^{70}$. Czeka na odpowiedź z ich strony, którego owocem jest zawsze nawrócenie serca i ufna modlitwa o miłosierdzie. W tych więc intencjach św. Faustyna podejmowała różne dzieła wpisujące się w służbę miłosierdziu Bożemu.

68 Dz. 742; por. Dz. 163, 742, 1029, 1148, 1158, 1249, 1313, 1316, 1685, 1768; L. Grygiel, Miłosierdzie Boże dla całego świata..., dz. cyt., s. 40-41; E. Matulewicz, Miłosierdzie Boże w charyzmacie Zgromadzenia Księży Marianów, Lublin 2007, s. 267-272.

${ }_{69}$ MV 10; por. C. Parzyszek, Znaczenie nowej ewangelizacji dla odnowy wspótczesnego świata, Ząbki 2012, s. 155-169.

70 Por. Dz. 740; L. Grygiel, Miłosierdzie Boże dla całego świata..., dz. cyt., s. 45-46; W. Seremak, Miłosierdzie Boże a Nowa Ewangelizacja..., dz. cyt., s. 125-173; E. Matulewicz, Miłosierdzie Boże w charyzmacie Zgromadzenia Księży Marianów, dz. cyt., s. 279-286. 
Chrystus, według Dzienniczka, wpisał także w ich strukturę dzieła miłosierdzia pełnione w duchu, których realizację polecał jego adresatom. Siostra Faustyna zaś, odpowiadając wielkodusznie na to wezwanie, oddawała się modlitwie ekspiacyjnej za wszystkich potrzebujących miłosierdzia. Z modlitwą łączyła codzienny krzyż i cierpienie. Składała je, w jedności z Chrystusem, w skarbcu Kościoła, który wychowuje i prowadzi do Boga. Wszystko czyniła dla zbawienia świata ${ }^{71}$.

Tak więc jej życie, mające charakter żertwy ofiarnej, przybrało niejako w Kościele i razem z Kościołem kształt doskonałej formy miłosierdzia Bożego. W takim też duchu angażowała się w wielorakie dzieła miłosierdzia i troszczyła się o świętość swojego życia i Kościoła ${ }^{72}$. Faktycznie żyła w Kościele nie tylko dla siebie, ale dla Kościoła i jego misji, co po latach znalazło wyraz w akcie jej kanonizacji.

\section{Zakończenie}

Przeprowadzona refleksja nad misją profetyczną św. Faustyny Kowalskiej wskazuje wyraźnie na istotne jej znaczenie dla misji Kościoła, którą ma do zrealizowania we współczesnym świecie. Jest wpisana w Jego misję, a jej korzenie sięgają sakramentów chrztu świętego i bierzmowania. Zachodzi między nimi głęboka identyfikacja. Misja prorocka św. Faustyny, udzielona przez Chrystusa w darze objawień, przypomina Kościołowi i ludzkości miłosierdzie Boże objawione w tajemnicy stworzenia świata i jego odkupienia. Z przeprowadzonej refleksji nasuwają się następujące wnioski:

1. Istnieje potrzeba kontynuowania, w świetle objawienia Bożego i nauczania Kościoła, refleksji teologicznej nad orędziem miłosierdzia Bożego przekazanym św. Faustynie, w celu głębszego odczytywania jego elementów treściowych.

71 Por. Dz. 740; KKK 1477, 2100; W. Seremak, Miłosierdzie Boże a Nowa Ewangelizacja..., dz. cyt., s. 90-95; J. Machniak, Błogosławiona siostra Faustyna Kowalska, Karków 1999, s. 74-78.

72 Por. Dz. 36, 67, 308, 604 , 749, 923, 1264, 1389, 1505, 1680, 1826; KKK 1477; C. Parzyszek, Znaczenie nowej ewangelizacji dla odnowy wspótczesnego świata, dz. cyt., s. 120-130; L. Grygiel, Miłosierdzie Boże dla całego świata..., dz. cyt., s. 41. 
2. Praca duszpasterska Kościoła domaga się ducha gorliwości i oddania św. Faustyny, by dar miłosierdzia Bożego dotykał serca i umysłu każdego człowieka. Światu potrzeba wiarygodnego zaangażowania. Święta Faustyna wlaną przez Ducha Świętego doktrynę o miłosierdziu Bożym potwierdziła świętością życia.

3. Ponieważ misja św. Faustyny jest wpisana w nową ewangelizację, trzeba ją realizować w jej stylu, tzn. drogą ufnej modlitwy, słowa i dzieł dobroczynnych. Wówczas miłosierdzie Boże, wnikając w serca ludzi, będzie ukazywało drogę powrotu do Boga Ojca, miłosiernego i kochającego wszystkich bez wyjątku.

4. Duszpasterstwo miłosierdzia nie sprowadza się tylko do upowszechniania jego form dewocyjnych, często powierzchownie i płytko. Istnieje potrzeba solidnej formacji duchowej, aby kształtowała się w świadomości Kościoła mentalność miłosierdzia.

5. Nawiązując do słów Dzienniczka, należy ufać, że św. Faustyna pełni nadal w Kościele misję Chrystusa. Zabiega gorliwym wstawiennictwem u Niego, aby miłosierdzie Boże było poznane, przyjęte i czczone ufną modlitwą, przepowiadaniem i pełnionymi dziełami miłosierdzia. 


\section{Summary}

\section{Misja profetyczna św. Faustyny Kowalskiej i jej znaczenie dla Kościoła we współczesnym świecie}

Struktura treściowa artykułu wprowadza w misję prorocką św. Faustyny Kowalskiej, którą otrzymała od Chrystusa jako wiedzę wlaną w darze szczególnego powołania. Przedmiotem tej misji jest miłosierdzie Boże, które zostało przypomniane Kościołowi i światu. Chrystus z treścią tego orędzia posłał ją do całego świata, mówiąc: „Dziś wysyłam ciebie do całej ludzkości z moim miłosierdziem”. On bowiem pragnie, aby dotarło ono do wszystkich ludzi. W jego realizacji poleca s. Faustynie, a przez nią Kościołowi, ufną modlitwę do miłosierdzia Bożego, jego przepowiadanie i ukazywanie w dziełach dobroczynnych. Tak więc misja św. Faustyny nie jest tylko jej osobistą, ale całego Kościoła. Jest wpisana w jego posłannictwo, które winien podejmować w duchu treści utrwalonych przez nią w Dzienniczku. Zatem jej misja ma szczególne znaczenie dla misji Kościoła, która charakteryzuje się ewangelicznym uniwersalizmem. Są w niej obecne także elementy eschatologiczne, których realizacja ma przygotować ludzkość na powtórne przyjście Chrystusa. Tym samym treść tej misji wpisuje się w przestrzeń nowej ewangelizacji. Faustyna realizowała ją zgodnie z Jego wolą, a więc według otrzymanych od Niego wskazań: w modlitwie, w słowach i w dziełach miłosierdzia. Powyższa triada zawiera w sobie pełnię objawionego jej miłosierdzia Bożego, które pragnie być obecne w życiu całego Kościoła i w jego działalności. Te więc elementy treściowe wyznaczyły strukturę niniejszego artykułu zakończonego wnioskami wynikającymi z przeprowadzonej refleksji.

Słowa kluczowe: miłosierdzie Boże, misja prorocka, Kościół, św. Faustyna

\section{The Prophetic Mission of Saint Maria Faustina Kowalska and its Significance for the Church of the Modern World}

The article introduces the prophetic mission of St. Maria Faustyna that she received from Jesus Christ as the Infused Knowledge with a gift of a special calling. The subject of this mission is God's Mercy which was reminded to the Church and the world. Jesus Christ sent her to the entire world with the message saying: "Today I am sending you with My mercy". He wants it to be reached by all the people. Jesus Christ order St. Maria Faustyna, and the whole Church, to realise the mission through the trusting prayer to the God's Mercy, its prediction and showing it in the charity works. So, the mission of St. Maria Faustyna is not only her personal one, but also the entire Church. It is a significant part of the Church mission which should be taken according to the contents of Diary: "Divine Mercy in My Soul". Therefore, her mission has got a significant meaning for the Church's mission which is characterised by the 
evangelical universalism. There are also eschatological elements which realisation is to prepare the humankind for the Second Coming of Jesus Christ. Thereby, the matter of this mission is accurate for the New Evangelism. St. Maria Faustyna was realising it according to His will, so by the directions got from Him: in the prayer, in words and in the acts of mercy. This triad consists of the completeness of revealed God's Mercy which wants to be present in the entire Church's life and its activity.

Those contents determined the structure of the article ended with conclusions ensuing from the reflections taken.

Keywords: God's mercy, prophetic mission, Church, St. Maria Faustina

\section{Bibliografia:}

Dekret o Apostolstwie Świeckich, w: Sobór Watykański II, Konstytucje. Dekrety. Deklaracje, Poznań 1968, s. 365-405.

Konstytucja dogmatyczna o Kościele, w: Sobór Watykański II, Konstytucje. Dekrety. Deklaracje, Poznań 1968, s. 87-170.

Konstytucja duszpasterska o Kościele w świecie wspótczesnym, w: Sobór Watykański II, Konstytucje. Dekrety. Deklaracje, Poznań 1968, s. 520-620.

Encyklika Ojca Świętego Jana Pawła II O Bożym Miłosierdziu Dives in Misericordia. Tekst $i$ komentarz, red. S. Grzybek, M. Jaworski, Kraków 1981.

Bulla Misericordiae vultus Ojca świętego Franciszka o Nadzwyczajnym Jubileuszu Miłosierdzia, Wrocław 2015.

Katechizm Kościoła Katolickiego, Poznań 1994.

Balter L., Kult Miłosierdzia Bożego w świetle „Dzienniczka” św. Faustyny, „Ateneum Kapłańskie" 85 (1993), s. 489-503.

Chmielewski M., Duchowość Miłosierdzia. Mały katechizm, Lublin 2017.

Dłutowski M., Przygotujesz świat na ostateczne przyjście moje. Profetyczna misja św. Faustyny Kowalskiej na podstawie Dzienniczka, Ząbki 2016.

Encyklopedia katolicka, t. 16, red. E. Gigilewicz i in., Lublin 2012.

Kowalska M. F., Dzienniczek. Miłosierdzie Boże w duszy mojej, Warszawa 2001.

Grygiel L., Miłosierdzie Boże dla całego świata. Błogosławiona Siostra Faustyna, Kraków 1993.

Machniak J., Błogosławiona siostra Faustyna Kowalska, Karków 1999.

Matulewicz E., Miłosierdzie Boże w charyzmacie Zgromadzenia Księży Marianów, Lublin 2007.

Miczyński J. K., Fundament duchowości i charyzmat Zgromadzenia Sióstr Matki Bożej Miłosierdzia, Lublin 2016.

Misiurek J., Źródło życia i świętości. Polska Teologia kultu Najświętszego Serca Jezusa, Lublin 2014.

Misiurek J., Wielkie mistyczki Kościoła, Lublin 1999.

Parzyszek C., Znaczenie nowej ewangelizacji dla odnowy wspótczesnego świata, Ząbki 2012. 
Rychłowski B., Jestem miłością i samym miłosierdziem. Orędzie Pana do błogosławionej siostry Faustyny, Warszawa 1994.

Seremak W., Miłosierdzie Boże a Nowa Ewangelizacja. Znaki czasu, Lublin 2001.

Sopoćko M., Miłosierdzie Boga w dziełach Jego, t. 1: Wcielenie-życie, nauczanie i czyny Jezusa Chrystusa, wyd. 3, Białystok 2017.

Sopoćko M., Miłosierdzie Boga w dziełach Jego, t. 3: Duch Święty, Kościót, łaska, cnota, dary Ducha Świętego, modlitwa, ufność, sakramenty święte, wyd. 3, Białystok 2017.

Urbański S., Mistyczny świat ducha, Warszawa 2000.

Witko A., Święta Faustyna i Miłosierdzie Boże, Kraków 2007. 